\title{
Prevention versus Clinical Management of Suicide Attempts in Adolescents: What are the Costs?
}

\author{
Prevención versus atención clínica \\ del intento de suicidio en adolescentes: \\ ¿cuáles son los costos?
}

Prevenção versus atenção clínica da tentativa de suicídio em adolescentes: quais são os custos?

Mónica María Ortegón Monroy, MD, MSc, DSc;

Ángela Martínez Céspedes, MD²

Isabel Pérez Olmos, MD, MSc*3

Received: March 31th, 2017 / Accepted: February 19th, 2018

Doi: http://dx.doi.org/10.12804/revistas.urosario.edu.co/revsalud/a.6764

To cite this article: Ortegón Monroy MM, Martínez Céspedes Á, Pérez Olmos I. Prevention versus Clinical Management of Suicide Attempts in Adolescents: What are the Costs? Rev Cienc Salud. 2018;16(2):188-202. Doi: http://dx.doi.org/10.12804/revistas.urosario.edu. co/revsalud/a.6764

\section{Abstract}

Introduction: Suicide is a worldwide public health problem, and youth are among the most affected population groups. In Colombia there is no evidence available about the cost of suicide care or prevention. This type of analysis is necessary to guide decisions about resource distribution in mental health and to reduce suicide rates amongst youths in our country. Thus, the purpose of this study is to estimate and compare the mean in-patient care cost of youth suicide attempts, with the mean cost of participation in a school-based suicide prevention program for adolescents. Materials and methods: Medical charts of adolescents hospitalized for suicide attempts were reviewed, along with registries from adolescent participants in a suicide prevention program in Bogotá in 2010. Resources used were identified and tariff costs were quantified. Results: The average in-patient cost of a teenage suicide attempt was $\$ 1814000$ colombian pesos (Cop) $(n=39)$ Colombian pesos, and of $\$ 10307000$ cop $(n=5)$

1 Public Health Research Group, School of Medicine and Health Sciences, Universidad del Rosario, Bogotá.

2 Organización Sánitas Internacional, Bogotá.

3 NeURos Research Group, Behavior and Mental Health research line. School of Medicine and Health Sciences, Universidad del Rosario, Bogotá.

*Corresponding author: isabel.perez@urosario.edu.co 
Colombian pesos when intensive care was required. The average cost of participation in a prevention program was $\$ 113000$ cop $(n=24)$ per high-risk teenager and of $\$ 47000$ cop $(n=101)$ for teenagers without suicide risk. Conclusion: With the average in-patient cost of one suicide attempt, 16 high-risk teenagers could be enrolled in a suicide prevention program.

Keywords: suicide, costs and cost analysis, prevention, hospitalization, adolescent, health policy.

\section{Resumen}

Introducción: el suicidio es un problema de salud pública mundial, siendo los jóvenes uno de los grupos poblacionales más afectados. En Colombia no hay evidencia disponible sobre el costo de la atención o de la prevención del suicidio. Este tipo de análisis es necesario para guiar las decisiones sobre la distribución de recursos en salud mental y reducir las tasas de suicidio juvenil en el país. Por lo tanto, el objetivo de este estudio es el de estimar y comparar el costo promedio de la atención médica del intento de suicidio de jóvenes, con el costo promedio de un programa escolar de prevención del suicidio, en adolescentes. Materiales y métodos: se revisaron las historias clínicas de los adolescentes atendidos en un hospital por intento suicida, y los registros de los adolescentes participantes en un programa de prevención del suicidio en 2010, en Bogotá. Se identificaron los servicios recibidos, cuantificándose su valor tarifario. Resultados: el costo promedio de la atención por paciente con intento de suicidio fue de $\$ 1814000(n=39)$, y de $\$ 10307000(n=5)$ cuando la atención requirió cuidado especializado. El costo promedio de la participación en el programa de prevención de suicidio fue de $\$ 113000(n=24)$ por adolescente de alto riesgo y de $\$ 47000(n=101)$ por adolescente sin riesgo. Conclusión: con el costo promedio de la atención de un intento suicida, se puede realizar un programa de prevención del suicidio con 16 adolescentes de alto riesgo.

Palabras clave: suicidio, costos y análisis de costo, prevención, hospitalización, adolescente, política de salud.

\section{Resumo}

Introdução: o suicídio é um problema de saúde pública mundial, sendo os jovens um dos grupos populacionais mais afetados. Na Colômbia não há evidência disponível sobre o custo da atenção ou da prevenção do suicídio. Este tipo de análise é necessário para guiar as decisões sobre a distribuição de recursos em saúde mental e reduzir as taxas de suicídios juvenil no país. Portanto, o objetivo deste estudo é estimar e comparar o custo da atenção médica da tentativa de suicídio de jovens, com o custo médio de um programa escolar de prevenção do suicídio em adolescentes. Materiais e métodos: revisaram-se as histórias clínicas dos adolescentes atendidos em um hospital por tentativa de suicídio, e os registros dos adolescentes participantes em um programa de prevenção do suicídio em 2010, em Bogotá. Identificaram-se os serviços recebidos, quantificando-se o valor tarifário dos mesmos. Resultados: o custo médio da atenção por paciente com tentativa de suicídio foi de $\$ 1814000$ (n = 39), e de $\$ 10307000$ ( $n=5$ ) quando a atenção requereu cuidado especializado. 0 custo médio da participação no programa de prevenção de suicídio foi de $\$ 113000(n=24)$ por adolescente de alto risco e de $\$ 47000$ ( $n=101)$ por adolescente sem risco. Conclusão: com o custo médio da atenção de uma tentativa suicida, se pode realizar um programa de prevenção do suicídio com 16 adolescentes de alto risco.

Palavras-chave: suicídio, custos e análise de custo, prevenção, hospitalização, adolescente, política de saúde. 


\section{Introduction}

Uicide is a worldwide public health problem and one of the 20 most frequent causes of death in the world (1). The prevalence of suicide attempts among the general population is between $0.4 \%$ and $4.2 \%$ annually. It is estimated that for every completed suicide there are between 10 and 20 suicide attempts among the general population (2). In 2016, the death rate from suicide among the general population in Colombia was 5.2 per 100000 inhabitants, which was the highest rate in the most recent 10 years (3). Youth are one of the most affected groups. According to statistics from the National Institute of Legal Medicine and Forensic Sciences, the number of deaths due to suicide at puberty and the beginning of adolescence has increased in 2016 and in previous years. The rate also increases during the course of adolescence and up to the age of young adulthood. Thus, in 2016, children nine years of age and under had a suicide rate of 0.09 per 100,000 persons, while those between 10 and 14 years had a rate of 2.13 per 100,000, 15-17-year-olds had a rate of 6.57 per 100,000, and 18-19-year-olds had a rate of 7.61 per 100,000. The highest rates among young people of both sexes were among the 18-19-year-olds, followed by 20-24-year-olds, with 7.61 and 7.59 suicides per 100,000, respectively (3).

From a social and psychological point of view, the losses related to completed suicides are evident, as are the harm and the sequelae of suicide attempts. The economic impact of these events is considerable due to the costs of healthcare and the loss of productivity resulting from the premature death of affected people (4-6). The few studies that have evaluated the costs and the economic impact of completed suicide and suicide attempts have been carried out in developed countries (4-8). The same is true for studies that evaluate the costs of suicide screening and prevention (9-11). The latter strategies are a priority, considering the extent to which some of the risk factors associated with suicidal behavior can be modified (12-17).

We do not have evidence available in Colombia regarding the cost of healthcare of suicide attempts or the costs of preventing such attempts. We also lack comparative studies on the economics of prevention strategies versus clinical care provided to the same population. This kind of analysis is necessary in order to guide decisions regarding the distribution of mental health resources that will help us reach the goal of reducing the country's suicide rate, especially among populations where it is most prevalent, such as among youth.

The goal of this study is to estimate and compare the average cost of hospital treatment provided to young inpatients after suicide attempts in the city of Bogotá with the average cost of an early mental health prevention strategy among young people from the same population. 


\section{Materials and methods}

\section{Screening and prevention program}

The goal of this program is the early detection of adolescents who are at risk for suicide or other mental health problems, and their referral to a program for specialized management. The program is under the auspices of the Columbia University TeenScreen Program and has been carried out annually in Bogotá since 2007 with students from a private secondary school under the guidance of the School of Medicine and Health Sciences of a private university in Bogotá, Colombia (18).

The screening consists of two sequential stages. A survey is distributed at the first stage in order to evaluate adolescents' emotional state, evidence of depression, and suicide risk. The second stage consists of a clinical interview focused on subjects' perceived mental state. The surveys evaluate the need for professional help based on participants' perceptions of their problems. The clinical interview seeks to provide more information and to characterize the kind of mental health or suicide risk identified at the first stage of screening $(15,19)$.

The screening classifies participants into two groups: 1. negative, without mental health risk or a need for intervention, and 2. positive, at risk for mental health problems and/or suicide. Youth in the positive group are also classified based on their risk for suicide and severity of depression. They are considered to be at high risk if they have engaged in suicidal behaviors (recent suicidal ideation or a suicide attempt at any time in their lives), most of them related to moderate to severe depression. They are classified at a lower level of risk if they merely require care for their emotional health, do not suffer from serious depression, and have no suicidal manifestations $(15,19)$.

The program identifies the specific needs of participants in the positive group: a consultation with a psychologist or a psychiatrist (generally for those at greatest risk) and family therapy in the case of moderate to severe family dysfunction on the Apgar Family assessment tool. In addition, students in the positive group - with or without suicidal manifestations - participate in between four and six psychosocial workshops for the development of social skills, self-esteem, and emotional intelligence as part of the strategy for mental health promotion. This program is described in greater detail in other publications $(15,18-21)$.

\section{Selection of study population}

Study population consisted of youth between 13-18 years of age in 2010. A tertiary pediatric hospital was selected for the identification of cases of hospital-based treatment. This hospital received most of the cases of emergency and other care from among the reference study population. The prevention group originated at the school where the program was 
implemented, and due to limited resources it was established at only one secondary grade level, the eighth grade, whose students are 13-16 years old.

Both the cooperating hospital and the school are located in northern Bogotá. In addition to sharing age, demographic, and geographical characteristics, the participants in both groups belong to low and middle socioeconomic strata.

\section{Identification of the study population}

Using the hospital database, patients who had been admitted to the Emergency Department with a diagnosis of attempted suicide (according to the International Classification of Diseases - ICD-10) were identified (22). This included patients diagnosed with codes X60-X84, corresponding to self inflicted injury or poisoning, and patients with mental and behavioral disorders diagnoseed with codes F00-F99 who presented with attempted suicide as the precipitating factor of their hospitalization, even if this was not their primary clinical diagnosis. The clinical charts of patients who were admitted and treated between January 1 and December 31, 2010 were reviewed and selected on this basis.

In the suicide prevention group, participants' records were selected from among the students who were registered in the program in 2010, and had written informed consent from both parents and students.

Criteria for exclusion from the study were incomplete or inconsistent information either in the screening and prevention program or in the clinical charts of those treated after attempting suicide.

This study was based on retrospective data collection techniques and involved no intervention among the study population. It was approved by two different ethics committees; the ethics commitee at the School of Medicine and Health Sciences of the university that coordinated the screening and prevention program, and the research ethics committee at the pediatric hospital where the cases of attempted suicide among adolescents were treated. The identity of participants and the confidentiality of information have been protected in conformity with national and international research standards. 


\section{Identification and quantification of costs}

The clinical charts and records of patients in the hospital's accounting system were reviewed to determine the resources used by each patient. Not only the types of resources used were registered, but also the number of times they were used. The resources used were grouped into the following service categories: hospitalization, laboratory and blood bank, imaging, additional consultations, medication, and supplies.

The values assigned to hospitalization, laboratory, radiology, diagnostic support, and additional consultations were obtained from the Price Schedule of the Colombian Social Security Institute (Manual Tarifario del Instituto de Seguros Sociales - MTISs).

The Social Security Price Schedule classifies activities, interventions, procedures, and tests carried out at healthcare institutions and assigns them prices, thus serving as a reference manual for the purchase and sale of healthcare services in the country (23). For the purpose of this study, the costs detailed in the manual and adjusted to 2010 prices were used, since it is the billing reference for the hospital in question. The cost of medications and supplies was calculated based on the tariff set by the hospital. It should be noted that mTiss prices include the cost component of the professional, technical, and paraprofessional services necessary for the application of all stated activities, interventions, procedures, and tests.

Information regarding resources used by the suicide prevention group was obtained from the program database, which includes information on the participation of students in screening activities, workshops, and other required services, contingent on the kind of mental health or suicide risk.

The 2010 salaries of researchers at the university's School of Medicine, as established by the administrators, were used to calculate the value of resources used at the screening stage. For the other two components (mental health consultations and workshops), mTiss rates established for consultations in 2010 were applied. In the case of psychosocial workshops, a standard value was applied based on the rate established by the mTiss for educational groups and group psychotherapy (23).

The costs were reported in Colombian pesos rounded to the nearest thousand and in United States dollars rounded to the nearest hundred.

4 Hospitalization: corresponds to patients' hospitalization in different departments, including observation in the emergency department. Laboratory and blood bank: includes paraclinical tests conducted during the hospital stay, as well as tests and procedures related to transfusional medicine (for example processing and administration of red blood cells). Imaging: includes diagnostic imaging methods comprising radiology, tomography, magnetic resonance, and ultrasound, as well as cardiological diagnostic methods such as echocardiograms and electrocardiograms). Additional consultations: include diagnosis and management of patients by specialists other than pediatricians during their hospital stay. These may include psychiatric, toxicological, pulmonological and other consultations. Medications and supplies: correspond to drugs and any devices required for their administration or for other necessary procedures (syringes, tubes, infusion pumps, etc.). 


\section{Results}

\section{Demographic characteristics}

In 2010, a total of thirty nine 13-18 year-old patients with diagnosis of attempted suicide were treated at the hospital (table 1). In this group, the most frequent exclusions stemmed from inconsistencies between the diagnosis of attempted suicide and data in the clinical chart: suicidal ideation with no attempted suicide, self-harm without any intention to commit suicide, or injuries due to accidents. The most common form of self-harm was poisoning (codes CIE10, X60-69), which was found in $85 \%$ of all cases $(n=33)$. Among the rest of the patients, the most common form of self-harm was self-inflicted injury (codes CIE10, X70-84) $(n=6)$. In 2010, 175 adolescents participated in this screening and prevention program. There were no exclusions (table 1).

Table 1. Age and sex distribution of attempted suicide cases treated in a hospital, and of participants in the school-based screening and prevention program, Bogotá, 2010

\begin{tabular}{|c|c|c|c|c|c|}
\hline \multirow{2}{*}{\multicolumn{2}{|c|}{ Demographic variables }} & \multicolumn{2}{|c|}{ Treatment } & \multicolumn{2}{|c|}{ Prevention } \\
\hline & & $\mathrm{N}(39)$ & $\%$ & N (175) & $\%$ \\
\hline \multirow{5}{*}{ Age in years } & 13 & 8 & 21 & 22 & 13 \\
\hline & 14 & 11 & 28 & 119 & 68 \\
\hline & 15 & 5 & 13 & 31 & 18 \\
\hline & 16 & 7 & 18 & 3 & 2 \\
\hline & $17-18$ & 8 & 21 & 0 & 0 \\
\hline \multirow{2}{*}{ Sex } & Female & 28 & 72 & 73 & 42 \\
\hline & Male & 11 & 28 & 102 & 58 \\
\hline
\end{tabular}

\section{Costs for the group receiving medical treatment for attempted suicide}

The cost of billing for the treatment of the 39 patients amounted to $\$ 70734000$ Colombian pesos (COP), corresponding to 106 days of hospital treatment. None of the patients was readmitted with the same diagnosis during the year 2010. The greatest billed costs were for medications and supplies, totaling $\$ 33238000$ cop, followed by hospitalization services costing $\$ 24506000$ cop. Taken together, these two line items came to more than $80 \%$ of all costs (table 2 ).

By dividing the billed costs among the 39 patients, the average cost per patient was $\$ 1814000$ (sD: \$5647000; $\mathrm{Cv}^{5}: 3.1$ ). The high variability of these data primarily results from different levels of utilization of resources related to hospitalization, in particular the

5 cv: Coefficient of variation. 
hospitalization of patients in more intensively monitored units, such as in intensive or intermediate care units, resulting in greater resource consumption.

Among the 39 patients, four required treatment in a pediatric intensive care unit, and one in an intermediate care unit. The cost of treatment for these five patients totaled $\$ 51534000$ cop, equivalent to $73 \%$ of the total treatment costs for all 39 cases. The average cost for treatment of patients placed in specialized units was $\$ 10307000$ cop (sD: $\$ 13994000$; cv: 1.4). The billed costs for the treatment of patients not requiring treatment in special units $(n=34)$ amounted to $\$ 19200000$ cop (sD: $\$ 657000$; cv: 1.2), with an average treatment cost of $\$ 565000$ cop per patient (table 2).

Table 2. Billed cost for hospital treatment of patients after attempted suicide in Bogotá, Colombia, 2010

\begin{tabular}{|c|c|c|c|c|c|c|}
\hline \multirow[t]{2}{*}{ Cost categories } & \multicolumn{2}{|c|}{$\begin{array}{l}\text { All patients } \\
\quad \mathrm{N}=39\end{array}$} & \multicolumn{2}{|c|}{$\begin{array}{l}\text { Treatment in } \\
\text { PICU and IMCU } \\
n=5\end{array}$} & \multicolumn{2}{|c|}{$\begin{array}{c}\text { Treatment in room, emergency } \\
\text { or observation unit } \\
\mathbf{n}=\mathbf{3 4}\end{array}$} \\
\hline & Cost & $\%$ & Cost & $\%$ & Cost & $\%$ \\
\hline Hospitalization & 24506000 & 35 & 17438000 & 34 & 7067000 & 37 \\
\hline $\begin{array}{l}\text { Medications } \\
\text { and supplies }\end{array}$ & 33238000 & 47 & 28858000 & 56 & 4380000 & 23 \\
\hline Laboratory & 7277000 & 10 & 4056000 & 8 & 3222000 & 17 \\
\hline $\begin{array}{l}\text { Additional } \\
\text { consultations }\end{array}$ & 4860000 & 7 & 414000 & 0.8 & 4092000 & 21 \\
\hline Imaging & 854000 & 1 & 768000 & 1.5 & 440000 & 2 \\
\hline Total & 70734000 & 100 & 51534000 & 100 & 19200000 & 100 \\
\hline $\begin{array}{l}\text { Average cost per } \\
\text { patient (sD) }\end{array}$ & \multicolumn{2}{|c|}{$1814000(5646000)$} & \multicolumn{2}{|c|}{$10307000(13994000)$} & \multicolumn{2}{|c|}{$565000(657000)$} \\
\hline $\begin{array}{l}90 \% \text { CIof average } \\
\text { cost }\end{array}$ & \multicolumn{2}{|c|}{$327000-3331000$} & \multicolumn{2}{|c|}{$12000-20602000$} & \multicolumn{2}{|c|}{$379000-750000$} \\
\hline $\begin{array}{l}\text { Median cost } \\
\text { per patient }\end{array}$ & \multicolumn{2}{|c|}{407000} & \multicolumn{2}{|c|}{2912000} & \multicolumn{2}{|c|}{363000} \\
\hline
\end{tabular}

Values in Colombian pesos, 2010. PICU: pediatric intensive care unit. IMCU: intermediate care unit. cr: confidence interval. SD: standard deviation.

The patients in specialized care units spent a total of 35 days hospitalized, with an average cost per day of $\$ 1200000$. Medicines and supplies were the most significant costs for this group, totaling more than half (56\%) of their total treatment costs, followed by the cost of hospitalization at $34 \%$ (table 2 ).

The 34 patients who did not require treatment in a specialized unit were hospitalized for a total of 71 days. The greatest use of resources among this group was for hospitalization (37\% of total costs). The cost of medications and supplies, consultations, and laboratory services was proportionally similar (table 2). 


\section{Average costs in the mental health and suicide prevention program}

The cost of the school screening and prevention program for the 175 participants was $\$ 11994000$. The cost of screening accounted for $68 \%$ of this figure (\$8159000); individual interventions, including assessment, psychological and psychiatric consultations, and family therapy represented $17 \%$; and the remaining $15 \%$ was attributable to mental health promotion (table 3 ). The average cost per participant in the program was $\$ 69000$ (SD: \$28000).

Table 3. Costs of the screening and prevention program for adolescent students at a school in Bogotá, Colombia. 2010.

\begin{tabular}{|c|c|c|c|c|c|c|c|c|c|c|}
\hline \multirow{3}{*}{ Cost category } & \multirow{2}{*}{\multicolumn{2}{|c|}{$\mathrm{N}=175$}} & \multirow{2}{*}{\multicolumn{2}{|c|}{$\begin{array}{l}\text { Negatively } \\
\text { assessed }\end{array}$}} & \multicolumn{6}{|c|}{ Positively assessed } \\
\hline & & & & & \multicolumn{2}{|c|}{$\begin{array}{c}\text { All } \\
n=74\end{array}$} & \multicolumn{2}{|c|}{$\begin{array}{l}\text { High risk } \\
\mathrm{n}=\mathbf{2 4}\end{array}$} & \multicolumn{2}{|c|}{$\begin{array}{c}\text { Low to mode- } \\
\text { rate } \\
\text { risk } \\
n=50\end{array}$} \\
\hline & Cost & $\%$ & Cost & $\%$ & Cost & $\%$ & Cost & $\%$ & Cost & $\%$ \\
\hline Screening & 8159000 & 68 & 4709000 & 100 & 3450000 & 47 & 1119000 & 41 & 2331000 & 51 \\
\hline $\begin{array}{l}\text { Individual } \\
\text { preventive } \\
\text { intervention }\end{array}$ & 2083000 & 17 & NA & NA & 2083000 & 29 & 1021000 & 38 & 1062000 & 23 \\
\hline $\begin{array}{l}\text { Mental health } \\
\text { promotion }\end{array}$ & 1752,000 & 15 & NA & NA & 1752000 & 24 & 5760004 & 21 & 1176000 & 26 \\
\hline Total & 11994000 & 100 & 4709000 & 100 & 7285000 & 100 & 2716000 & 100 & 4569000 & 100 \\
\hline $\begin{array}{l}\text { Average cost Per } \\
\text { case (SD) }\end{array}$ & \multicolumn{2}{|c|}{$69000(28000)$} & \multicolumn{2}{|c|}{$47000(0)$} & \multicolumn{2}{|c|}{$98000(16000)$} & \multicolumn{2}{|c|}{$113000(0)$} & \multicolumn{2}{|c|}{$91000(15000)$} \\
\hline
\end{tabular}

Values in Colombian pesos, 2010. sD: Standard deviation.

Some type of emotional risk and/or a perceived need for professional help was identified among 74 of the 175 participating youth (42\%). All of these positively-identified students were referred to a psychological consultation, and 45 of them required a psychiatric consultation as well. Seventy three students participated in psychosocial workshops. The implementation of the program for positive students had a cost of $\$ 7285000$, equivalent to $60 \%$ of the total program cost. The average cost per positive adolescent was $\$ 98000$ (sD: \$16000) (table 3).

Within the group of positive students, $14 \%$ were found to be at high emotional risk and risk of suicide $(n=24)$. All the adolescents in this group required a psychological consultation, a psychiatric consultation, an assessment and a family therapy session, and attendance to four psychosocial workshops. The cost of the screening and prevention activities for high risk youth was $\$ 2716000$, with an average cost per case of $\$ 113000$. 
Students in the program at low or moderate emotional and mental risk $(n=50)$ resulted in an average cost of $\$ 91000$ (sD: \$15000). Among this group, 21 adolescents were referred to a psychiatric consultation; 17 required assessment and family intervention, and 49 attended four sessions of psychosocial workshops. Approximately $40 \%$ of the total program cost, equivalent to $\$ 4569000$, was attributable to low to moderate-risk participants.

The only cost to the program attributable to students classified as negative ( $n=101)$ was spent for screening tests. Since these participants were mentally and emotionally healthy, they did not require any intervention. The average cost per screened student was $\$ 47000$.

For reference purposes, tables 4 and 5 provide the costs in U.S. dollars for the hospital treatment of patients who had attempted suicide and for the costs of the school-based screening and prevention program, respectively. Prices in Colombian pesos were converted to dollars using the representative exchange rate for 2010 of 1897 cop $=1$ usD (24).

Table 4. Billed cost in dollars for treatment of adolescents who attempted suicide at a hospital in Bogotá, Colombia in 2010

\begin{tabular}{|c|c|c|c|c|c|c|}
\hline \multirow[t]{2}{*}{ Cost categories } & \multicolumn{2}{|c|}{ All patients } & \multicolumn{2}{|c|}{$\begin{array}{c}\text { Treatment in picu and } \\
\text { IMCU }\end{array}$} & \multicolumn{2}{|c|}{$\begin{array}{c}\text { Treatment in room, } \\
\text { observation unit, and } \\
\text { emergency department } \\
n=34\end{array}$} \\
\hline & Cost & $\%$ & Cost & $\%$ & Cost & $\%$ \\
\hline Hospitalization & 12900 & 35 & 9200 & 34 & 3700 & 37 \\
\hline $\begin{array}{l}\text { Medications } \\
\text { and supplies }\end{array}$ & 17500 & 47 & 15200 & 56 & 2300 & 23 \\
\hline Laboratory & 3800 & 10 & 2100 & 8 & 1700 & 17 \\
\hline $\begin{array}{l}\text { Additional } \\
\text { consultations }\end{array}$ & 2600 & 7 & 400 & 1 & 2200 & 21 \\
\hline Imaging & 500 & 1 & 200 & 1 & 200 & 2 \\
\hline Total & 37300 & 100 & 27200 & 100 & 10100 & 100 \\
\hline $\begin{array}{l}\text { Average cost } \\
\text { per patient (sD) }\end{array}$ & 100 & & & & & \\
\hline CI $90 \%$ & & & & & & \\
\hline $\begin{array}{l}\text { Median cost } \\
\text { per patient }\end{array}$ & & & & & & \\
\hline
\end{tabular}

Values in U.S. dollars (USD), 2010. PICU: Pediatric intensive care unit. IMCU: Intermediate care unit. cI: confidence intervals. SD: Standard deviation. 
Table 5. Costs in dollars for the screening and prevention program for adolescents at a school in Bogotá, Colombia, 2010

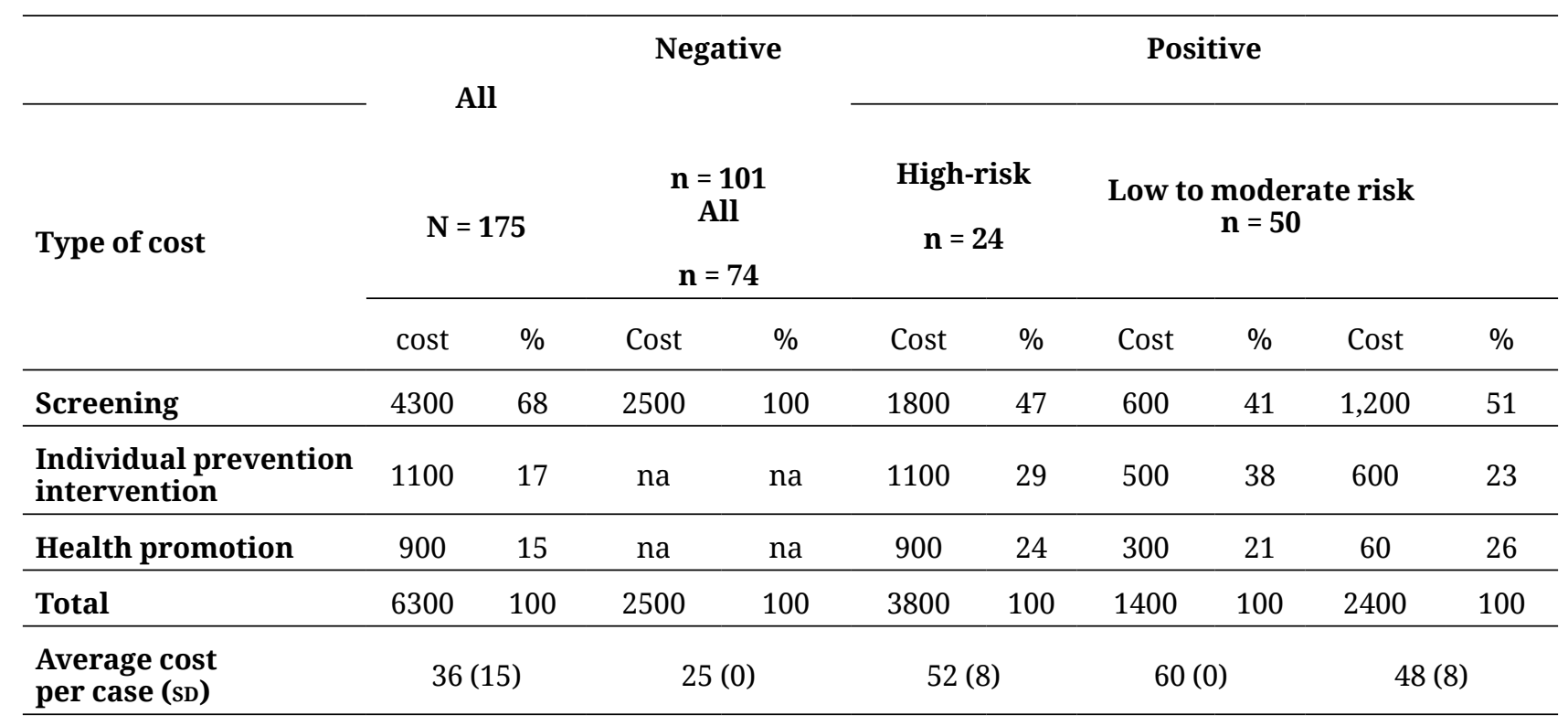

Values in U.S. dollars (USD), 2010. SD: Standard deviation.

\section{Discussion}

This study has quantified the direct medical costs for hospital treatment of young people admitted to a hospital after attempted suicide, and the costs of a school-based prevention strategy for mental health among adolescents. As far as we know, this is the first study in the published literature that quantifies and compares the costs of a mental health prevention intervention (primary and early secondary) with the costs of an acute care intervention. In 2010, the direct medical cost of the treatment provided in 39 cases of attempted suicide among youth at the hospital where this study took place was $\$ 70734000$, and the cost of implementing the prevention strategy for 175 adolescents was $\$ 11994000$. The average cost of hospital treatment after attempted suicide was $\$ 1814000$ per patient, and in the case of the prevention program, the average cost per high risk student identified and treated was $\$ 113000$.

These resulting estimates were derived using an ingredients-based costing methodology, by means of which the total resources required to carry out each intervention were identified, as were their physical quantities. This methodology involves a demanding process, but exhibits greater precision and transparency. Each resource was assigned a reference value based on the price most commonly billed to health insurers in Colombia. Since the perspective of the study was that of the third party payer, billing prices rather than the economic value of resources were used. This approach is an advantage of the study since the costs here reported represent the actual costs that financial entities or health insurers would incur for hospital treatment of 
suicide attempts or for mental health prevention in the form of an early detection and referral program for their young affiliates as described here.

Another methodological characteristic of the study is that the population for both interventions was selected taking into account the socioeconomic condition and strata, as well as geographical location, in order to maximize the homogeneity of the two groups with respect to the measure of interest. This matters because of the variation in the access and use of health services among socioeconomic strata described in our context (25).

This study attests to the high cost of hospital-based healthcare after attempted suicide, in keeping with the published literature in this field $(4,6,8)$. This cost is even higher when treatment in specialized hospital units is required. In our study, the per-diem cost of hospitalization in a specialized care unit was almost four times the per-diem cost of hospitalization in other units. The association between high costs and hospitalization in specialized units after attempted suicide has been described in a previous study in a developed country, although the discrepancy was less extreme there, with the daily costs of hospitalization in an intensive care unit being less than two times the cost of hospitalization in other units (4).

Both the annual cost and the average cost of the prevention program were lower than the cost of medical treatment after attempted suicide. For a precise comparison of the cost of these interventions, we refer to the cost per adolescent receiving each of them. Focusing on high-risk adolescents, the group common to both subpopulations (those of greatest interest for identification in the prevention strategy and those who make up the majority of cases of attempted suicide who are then admitted to a hospital), we see that among the population studied, it is 16 times less costly to implement a suicide prevention strategy (\$113000), than to provide hospital treatment after an attempted suicide (\$1814000), in a high-risk adolescent from the population here studied.

These results demonstrate the economic advantage of suicide prevention compared to providing medical attention after attempted suicide among youth. But more important than pointing to the advantage of one strategy over the other, we believe that the usefulness of our results lies in the contribution to establishing the priority that should be given to the different strategies for adolescent mental health. It is clear that an appropriate strategy in this field should include early prevention activities as well as treatment for the mental condition in both its acute and chronic forms. With this in mind, and from the point of view of cost containment, we believe that early detection programs and intervention for suicidal risk such as the mental health and suicide screening and prevention program evaluated here should be emphasized as part of the strategy for reducing youth suicide in our context. At the same time, we are aware this is a preliminary study; to confirm the above and corroborate the desirability of implementing the program at other schools in Bogotá or in other cities, further economic analysis is needed, as are studies of effectiveness and cost effectiveness in this field. 
This study not only quantifies and compares the costs of the two interventions considered, but also provides a detailed description of the use of resources and services in implementing them. This information is useful in improving our knowledge of health care in the case of hospital treatment for attempted suicide, and for the planning of an eventual implementation in the case of the suicide risk screening and prevention program.

One limitation of our study is that it did not include the ambulatory cost of attempted suicide, reason why our results do not reflect the total direct medical cost of this event among young patients. Nor did we include the costs of hospital-based psychiatric treatment provided to the three patients who were referred to a second institution due to the lack of a mental health unit in the hospital considered in the study. Had these costs been included, the difference between the two strategies would have been greater.

The distribution of hospital costs in the study was highly variable, as is the case in most studies that evaluate healthcare costs. This was due to the four outliers: three high cost cases and one extremely high cost case. For this reason, and in order to adequately describe and report our results, we performed subgroups analysis and reported, aside from mean costs, confidence intervals, medians, and measures of dispersion. It is worth noting that the effect of these extreme cases can lead to a cost overestimate in small size studies such as our own, thus the importance of subgroups analysis.

To conclude, conducting a strategy of suicide prevention and mental health promotion among youth is much less costly than providing hospital-based medical treatment after a young person attempts suicide, especially if patients who have attempted suicide require treatment in a specialized, intensive, or intermediate care unit.

In quantitative terms, with the average cost of treating one patient with suicide attempt (\$1 813704), 16 high-risk adolescents could be enrolled in a school-based suicide prevention program.

Given the desire to minimize the use of resources, school-based suicide prevention programs like the one described here is an advantageous option, particularly in contexts with limited resources such as our own. Nonetheless, their wider implementation requires additional evidence provided by other research designs.

\section{Acknowledgments}

W e thank Dr. Norman Sartorius and the AImHP (http://aim-mental-health.org/) for their economic support of the mental health and suicide prevention screening program for adolescents, as well as Dr. M. Cárdenas for providing treatment to the students at risk for suicide, and to all those who collaborated with both program strategies. 


\section{Conflict of interest}

The opinions expressed in this article are those of the authors, all of whom state that they have no conflict of interest. The study received no external financing. This article results from the work of Ángela Martínez Céspedes toward her postgraduate thesis in pediatrics with the methodological and conceptual guidance from the other two authors.

\section{References}

1. World Health Organization who. Preventing Suicide: How to Start a Survivors Group. Geneve: World Health Organization (wHo) [internet]. 2004 [cited 2014 Aug 04]. Available from: http://www.who.int/mental_health/prevention/suicide/resource_survivors.pdf

2. Beautraklis A, Mishara B. World Suicide Prevention Day. September 10, 2007: "Suicide Prevention across the Life Span”. Crisis. 2007; 28(2):57-60. doi: 10.1027/0227-5910.28.2.57

3. Instituto Nacional de Medicina Legal y Ciencias Forenses. Forensis 2016, Datos Para la Vida. Bogotá: Instituto Nacional de Medicina Legal y Ciencias Forenses. 2017. Available from: http://www.medicinalegal.gov.co/documents/88730/4023454/Forensis+2016++Datos+para+la+Vida.pdf/af636ef3-0e84-46d4-bc1b-a5ec71ac9fc1

4. Czernin S, Vogel M, Fluckiger M, Muheim F, Bourgnon JC, Reichelt M, et al. Cost of attempted suicide: a retrospective study of extent and associated factors. Swiss Med Wkly. 2012;142:w13648. doi: 10.4414/smw.2012.13648

5. Knox KL, Caine ED. Establishing priorities for reducing suicide and its antecedents in the United States. Am J Public Health. 2005;95(11):1898-903. doi: 10.2105/AJPH.2004.047217

6. O'Dea D, Tucker S. The Cost of Suicide to Society. Wellington: Ministry of Health [internet]. 2005 [cited 2013 Oct 30]. Available from: http://www.health.govt.nz/system/ files/documents/publications/thecostofsuicidetosociety.pdf

7. Kennelly B. The economic cost of suicide in Ireland. Crisis. 2007;28(2):89-94. doi: 10.1027/0227-5910.28.2.89

8. Stensland MD, Zhu B, Ascher-Svanum H, Ball DE. Costs associated with attempted suicide among individuals with bipolar disorder. J Ment Health Policy Econ. 2010;13(2):87-92.

9. Chatterji P, Caffray CM, Crowe M, Freeman L, Jensen P. Cost Assessment of a School-Based Mental Health Screening and Treatment Program in New York City. Adm Policy Ment Health. 2004;09;6(3):155-66.

10. Kuo E, Vander SA, McCauley E, Kernic MA. Cost-effectiveness of a school-based emotional health screening program. J Sch Health. 2009;79(6):277-85. doi: 10.1111/j.17461561.2009.00410.x

11. Mihalopoulos C, Vos T, Pirkis J, Carter R. The population cost-effectiveness of interventions designed to prevent childhood depression. Pediatrics. 2012;129(3):e723-30. doi: 10.1542/ peds.2011-1823

12. Agerbo E, Nordentoft M, Mortensen PB. Familial, psychiatric, and socioeconomic risk factors for suicide in young people: nested case-control study. BMJ. 2002;325(7355):74. 
13. Gómez C, Rodríguez N, Bohórquez A, Diazgranados N, Ospina M, Fernández C. Factores asociados al intento suicida en la población colombiana. Rev Colomb de Psiquiatr 2002;31(4):271-86.

14. Moscicki EK. Identification of suicide risk factors using epidemiologic studies. Psychiatr Clin North Am 1997; 20(3):499-517. doi: 10.1016/S0193-953X(05)70327-0

15. Pérez-Olmos I, Téllez DL, Vélez A, Ibanez-Pinilla M. Caracterización de factores asociados con comportamiento suicida en adolescentes estudiantes de octavo grado, en tres colegios bogotanos. Rev Colomb Psiquiatr. 2012; 41(1):27-47.

16. Pérez-Olmos I, Ibánez-Pinilla M, Reyes-Figueroa JC, Atuesta-Fajardo JY, Suárez-Díaz MJ. Factors associated with suicide attempts and persistent suicidal ideation at a Primary Care Unit in Bogota, 2004-2006. Rev Salud Publica (Bogota). 2008; 10(3):374-85.

17. Pérez-Olmos I, Rodríguez-Sandoval E, Dussan-Buitrago MM, Ayala-Aguilera JP. Psychiatric and social characterisation of suicide attempts treated at a children's clinic, 2003-2005. Rev Salud Publica (Bogota). 2007; 9(2):230-40. doi: 10.1590/S0124-00642007000200007

18. Shaffer D, Scott M, Wilcox H, Maslow C, Hicks R, Lucas CP, et al. The Columbia Suicide Screen: validity and reliability of a screen for youth suicide and depression. J Am Acad Child Adolesc Psychiatry. 2004;43(1):71-9. doi: 10.1097/00004583-200401000-00016

19. Pérez-Olmos I, Gómez V, Ibanez-Pinilla M. Validity and Reliability of the Columbia Health Screen (cHs), Instrument of the Youth Mental Health and Suicide Screening Program of Rosario University, Bogota, a Subsidiary of the "Columbia University TeenScreen Program”. Mind \& Brain, The Journal of Psychiatry (Jop). 2012

20. Forero LM, Avendano MC, Duarte ZJ, Campo A. Consistencia interna y analisis de factores de la escala apgar para evaluar el funcionamiento familiar en estudiantes de basica secundaria. Rev Colomb Psiquiat. 2006; 35(1):23-9.

21. Scott M, Wilcox H, Huo Y, Turner JB, Fisher P, Shaffer D. School-based screening for suicide risk: balancing costs and benefits. Am J Public Health [internet]. 2010; 100(9):164852. doi: 10.2105/AJPH.2009.175224

22. Organización Mundial de la Salud. Clasificación Internacional de Enfermedades CIE-10. Madrid: Organización Mundial de la Salud (oмs). 1992. Available from: http://ais.paho. org/classifications/Chapters/pdf/Volume1.pdf

23. Instituto de Seguros Sociales. Acuerdo No. 256 de 2001. Manual de Tarifas de la Entidad Promotora de Salud del Seguro Social “EPS-ISs”. Bogota, Colombia: Instituto de Seguros Sociales. 2001. Available from: https://lexsaludcolombia.files.wordpress.com/2010/10/ tarifas-iss-2001.pdf

24. Banco de la República. Tasa de cambio del peso colombiano, Serie Histórica. Bogotá: Banco de la República 2010. Available from http://www.banrepgovco/es/trm

25. García-Subirats I, Vargas I, Mogollón-Pérez AS, De Paepe P, da Silva MR, Unger JP, et al. Inequities in access to health care in different health systems: a study in municipalities of central Colombia and north-eastern Brazil. Int J Equity Health 2014; 13:10. doi: 10.1186/1475-9276-13-10 